\title{
Second international congress on immunopharmacology: delivery systems and current strategies for drug design
}

\author{
Reinaldo Acevedo ${ }^{1 *}$, Mario Landys ${ }^{1}$, Armando Acosta ${ }^{1}$, Herve Bercovier ${ }^{2}$, Mohd Nor Norazmi ${ }^{3,4}$, Valerie Ferro ${ }^{5}$, \\ Maria Elena Sarmiento ${ }^{1}$
}

From Second International Congress on Immunopharmacology 2011

Varadero Beach, Cuba. 26-30 June 2011

The $2^{\text {nd }}$ International Congress on Immunopharmacology was held in June of 2011 at the Conference Center of Plaza America in Varadero, Cuba. The main goal of this meeting was to provide state-of-the-art communications for scientists, manufacturers, regulators and healthcare workers, to accelerate progress in the development of biological and biotechnological products and to promote exchange/scientific cooperation between researchers. 300 delegates from 22 countries attended the conference. The wide-ranging programme commenced with a plenary session and then split into a series of parallel workshops and symposia, covering "Advances in Immunopharmacology", "Neuroimmunology", "Therapeutic Biological Products", "Prophylaxis and Treatment of Helicobacter pylori", "Pharmacology of Cytochrome P450", "Hereditary Ataxias" and "Delivery Systems and Current Strategies for Drug Design". In this last Symposium, a substantial body of data was presented relating to the development of delivery systems with adjuvant and vaccine potential and also to strategies focused in therapeutic and prophylactic approaches against tuberculosis. This issue is dedicated to some of the results presented in this area.

Particulated structures have been used for more than two decades in the formulation of vaccine candidates, even before nanotechnology became a common field on its own. Virus-like particles and outer membrane vesicles (OMV) based vaccines were shown to have prophylactic potential against various infections [1]. Soluble antigens obtained through recombinant or synthetic processes have been known to be less immunogenic than antigens

\footnotetext{
* Correspondence: racevedo@finlay.edu.cu

${ }^{1}$ Finlay Institute. Ave. 27 No. 19805, La Lisa. La Habana, Cuba. AP. 16017,

CP11600

Full list of author information is available at the end of the article
}

associated with nanoparticles [2]. Traditional inactivated and attenuated whole vaccines have immunostimulatory components, like LPS and DNA, which also account for toxic reactions associated to such vaccines. However, these molecules, which are also referred to as natural adjuvants [3], may trigger signals to activate cellular pathways that potentiate the immune response to antigens in the vaccine formulation [3]. Development of bacterial derived nano/microparticles takes advantage of such immunostimulatory effects of the antigenic repertoire expressed in the outer membrane of microorganisms [4]. OMV vaccines against Neisseria meningitidis serogroup B were developed as both adjuvant [4] and vaccine [1]. Furthermore, OMV and cochleates obtained from bacteria have been effectively used via the mucosal route to induce systemic as well as mucosal immune responses [5]. This and other approaches have promoted research and development of novel particulated structures from Vibrio cholerae, Bordetella pertussis, N. meningitidis and Mycobacteria [6,7]. Presentations related with these areas are included in this supplement. Research related with the identification of antigens of $M$. tuberculosis with vaccine potential using in silico methods as well as work related with potential markers of tuberculosis infection are also included.

The potential importance of the specific antibody response against tuberculosis is a subject of growing interest [8-14] and a report on the protective role of antibody formulations against mycobacteria is also presented.

We are very grateful to BMC Immunology for agreeing to publish this group of presentations of the symposium.
Ciomed Central

() 2013 Acevedo et al; licensee BioMed Central Ltd. This is an Open Access article distributed under the terms of the Creative Commons Attribution License (http://creativecommons.org/licenses/by/2.0), which permits unrestricted use, distribution, and reproduction in any medium, provided the original work is properly cited. 


\section{Declarations}

This article has been published as part of BMC Immunology Volume 14 Supplement 1, 2013: Proceedings from Delivery Systems and Current strategies to drug design. The full contents of the supplement are available online at http://www.biomedcentral.com/bmcimmunol/supplements/14/S1

\section{Author details}

${ }^{1}$ Finlay Institute. Ave. 27 No. 19805, La Lisa. La Habana, Cuba. AP. 16017, CP11600. ${ }^{2}$ Faculty of Medicine, Hebrew University of Jerusalem, Israel.

${ }^{3}$ Schools of Health Sciences Universiti Sains Malaysia, 16150 Kubang Kerian, Kelantan, Malaysia. ${ }^{4}$ Institute for Research in Molecular Medicine, Universiti Sains Malaysia, 16150 Kubang Kerian, Kelantan, Malaysia. ${ }^{5}$ University of Strathclyde, Strathclyde Institute of Pharmacy and Biomedical Sciences (SIPBS), Glasgow, Scotland, UK.

Published: 25 February 2013

\section{References}

1. Sierra G, Campa HC, Varcacel NM, Izquierdo PL, Sotolongo PF, Casanueva GV, García L: Vaccine against group B Neisseria meningitidis. Protection trial and mass vaccination results in Cuba. NIPH Ann 1991, 14(2):195-210

2. Singh $M$, Chakrapani $A, O^{\prime}$ Hagan D: Nanoparticles and microparticles as vaccine-delivery systems. Expert Rev Vaccines 2007, 6(5):797-808.

3. Leroux-Roels $\mathrm{G}$ : Unmet needs in modern vaccinology: adjuvants to improve the immune response. Vaccine 2010, 28S:25-36.

4. Pérez O, Bracho G, Lastre M, González D, del Campo J, Zayas C, Acevedo R, Barberá R, Sierra G, Labrada A, et al: Proteoliposome nanoparticle for vaccine adjuvants. In Bionanotechnology: Global Prospective. CRC Press, Taylor and Francis Group;DE R 2008:123-130.

5. Pérez O, Lastre M, Cabrera O, del Campo J, Bracho G, Cuello M, Acevedo R: New Vaccines Require Potent Adjuvants like AFPL1 and AFCo1. Scand J Immunol 2007, 66:271-277.

6. Rodríguez $L$, Tirado $Y$, Reyes F, Puig A, Kadir R, Borrero R, Fernández S, Reyes G, Álvarez N, García MA, Sarmiento ME, Norazmi MN, Pérez Quinoy $J$, Acosta A: Proteoliposomes from Mycobacterium smegmatis induce immune cross-reactivity against Mycobacterium tuberculosis antigens in mice. Vaccine 2011, 29(37):6236-41.

7. Nguyen Thi Le Thuy, Maura Reinier Borrero, Férnandez Sonsire, Reyes Giselle, Luis Perez José, Reyes Fátima, de los Angeles García María, Fariñas Midrey, Infante Juan Francisco, Tirado Yanely, Puig Alina, Sierra Gustavo, Álvarez Nadine, Ramírez Juan Carlos, Sarmiento María Elena, Norazmi Mohd-Nor, Acosta Armando: Evaluation of the potential of Mycobacterium smegmatis as vaccine Candidate against tuberculosis by in silico and in vivo studies. VacciMonitor 2010, 19(1):20-26.

8. Olivares N, León A, López Y, Puig A, Cádiz A, Falero G, Martínez M, Sarmiento ME, Fariñas M, Infante JF, Sierra G, Solís RL, Acosta A: The effect of the administration of human gamma globulins in a model of BCG infection in mice. Tuberculosis 2006, 86(3-4):268-273.

9. Olivares N, Puig A, Aguilar D, Moya A, Cádiz A, Otero O, Izquierdo L, Falero G, Solis RL, Orozco H, Sarmiento ME, Norazmi MN, HernándezPando R, Acosta A: Prophylactic effect of administration of human gamma globulins in a mouse model of tuberculosis. Tuberculosis 2009, 89(3):218-20.

10. López Y, Yero D, Falero-Diaz G, Olivares N, Sarmiento ME, Sifontes S, Solis RL, Barrios JA, Aguilar D, Hernández-Pando R, Acosta A: Induction of a protective response with an IgA monoclonal antibody against Mycobacterium tuberculosis $16 \mathrm{kDa}$ protein in a model of progressive pulmonary infection. Int J Med Microbiol 2009, 299(6):447-452.

11. López Y, Falero-Díaz G, Yero D, Solís R, Sarmiento ME, Acosta A: Antibodies in the protection against mycobacterial infections: what have we learned? Procedia in Vaccinology 2010, 2(2):172-177.

12. Acosta A, Norazmi MN, Sarmiento ME: Antibody mediated immunity A missed opportunity in the fight against tuberculosis? Malaysian J Med Sci 2010, 17(2):66-67.

13. Acosta A, López $Y$, Norazmi MN, Hernández Pando R, Alvarez N, Sarmiento ME: Towards a new challenge in TB control: Development of antibody-based protection. In "Mycobacterium tuberculosis/Book 3" Pere Cardona 979-953-307-698-9 2012
14. Glatmann-Freeedman A: The role of antibodies against tuberculosis. In The Art \&Science of tuberculosis vaccine development. 1 edition. Malaysia. Oxford University Press;Norazmi MN, Acosta A, Sarmiento ME 2010:186-208.

doi:10.1186/1471-2172-14-S1-S1

Cite this article as: Acevedo et al:: Second international congress on immunopharmacology: delivery systems and current strategies for drug design. BMC Immunology 2013 14(Suppl 1):S1.

\section{Submit your next manuscript to BioMed Central and take full advantage of:}

- Convenient online submission

- Thorough peer review

- No space constraints or color figure charges

- Immediate publication on acceptance

- Inclusion in PubMed, CAS, Scopus and Google Scholar

- Research which is freely available for redistribution

Submit your manuscript at www.biomedcentral.com/submit
Ciomed Central 